\title{
Stage IS Testicular Cancer AJCC v6 and v7
}

National Cancer Institute

\section{Source}

National Cancer Institute. Stage IS Testicular Cancer A/CC v6 and v7. NCI Thesaurus.

Code C6363.

Stage IS includes: Any pT/TX, N0, M0, S1-3. pTX: Primary tumor cannot be assessed. N0: No regional lymph node metastasis. M0: No distant metastasis. S1: LDH less than $1.5 \mathrm{x}$ $\mathrm{N}$ ( $\mathrm{N}$ indicates the upper limit of normal for the LDH assay) and hCG less than 5,000 and AFP less than 1,000. S2: LDH 1.5-10 x N or hCG 5,000-50,000 or AFP 1,000-10,000. S3: LDH more than $10 \times \mathrm{N}$ or hCG more than 50,000 or AFP more than 10,000. (AJCC 6th and 7th eds.) 